\title{
REMOVAL OF METHYLENE BLUE BY USING BIOSOLID
}

\author{
M. SARIOGLU ${ }^{1}$ \\ U.A. ATAY ${ }^{2}$
}

\author{
${ }^{1}$ Department of Environmental Engineering \\ Cumhuriyet University, 58140-Sivas, Turkey \\ ${ }^{2}$ Department of Environmental Engineering \\ Cumhuriyet University \\ 58140-Sivas, Turkey
}

Received: 30/5/2005

Accepted: 15/2/2006 *to whom all correspondence should be addressed: e-mail: sarioglu@cumhuriyet.edu.tr

\section{ABSTRACT}

The mechanism of Methylene Blue adsorption on biosolid (waste sludge) has been studied through batch experiments. The effects of various experimental parameters, such as $\mathrm{pH}$ (311), biosolid dosage (1-10 $\left.\mathrm{g} \mathrm{l}^{-1}\right)$, contact time (5-1440 min) and initial dye concentration were investigated. The results showed that the dye removal increased with increase in the initial concentration of the dye and also increased in amount of biosolid used and initial $\mathrm{pH}$. Adsorption data was modeled using the Freundlich adsorption isotherm. The results show that biosolid could be employed effective and low cost material for removal of dyes and colour from aqueous solution.

KEYWORDS: Methylene blue, dye, Freundlich adsorption isotherm

\section{INTRODUCTION}

The effluents from textile, leather, food processing, dyeing, cosmetics, paper, and dye manufacturing industries are important sources of dye pollution [1]. Many dyes and their break down products may be toxic for living organisms [2]. Therefore, decolorizations of dyes are important aspects of wastewater treatment before discharge. It is difficult to remove the dyes from the effluent, because dyes are not easily degradable and are generally not removed from wastewater by conventional wastewater systems [3]. Generally biological aerobic wastewater systems are not successful for decolorization of majority of dyes [2]. Therefore, color removal was extensively studied with physco-chemical methods as coagulation, ultra-filtration, electro-chemical adsorption and photo-oxidation [2,4].

Among these methods, adsorption is a widely used for dye removal from wastewaters $[4,5]$. Granulated activated carbon (GAC) or powdered activated carbon (PAC) is commonly used for dye removal $[5,6,7]$. However, they are expensive and the regeneration or disposal of it has several problems. Thus, the use of several low cost adsorbents has been studied by many researches. They have studied the feasibility of using low cost materials, such as waste orange peel [8]; banana bith [9]; cotton waste, rice husk [10]; betonite clay [11]; Neem leaf powder [5]; powdered activated sludge [4]; perlite [12]; bamboo dust, coconut shell, groundnut shell, rice husk, and straw [2]; duck weed [13] and sewage sludge [14] as a adsorbents for removal of various dyes from wastewaters. Among these materials, adsorption of Methlylene Blue (basic dye) was investigated by above mentioned references [2, 5, 12, 13, 14].

Biological wastewater treatment produces a biological sludge (biosolid) including of inert materials and microorganisms. Return activated sludge (RAS) or waste activated sludge (WAS) can be used for biosorption of dye-contaminated industrial effluents. RAS consists of a variety of living organisms. However, waste activated sludge (WAS) consists of the non-living microorganisms. In this sense, in this study, dewatered nonliving WAS was used after belt- 
filtration. Waste sludge was conditioned with lime before belt-filter. So, filter cake (biosolid) was used for dye (Methlylene Blue) removal studies.

This study was designed to investigate the effects of sorbent concentration, $\mathrm{pH}$ contact time and initial dye concentration on the sorption capacity by using Methlylene Blue dye. Freundlich isotherm was performed for interpretation of results.

\section{MATERIAL AND METHODS}

The adsorption experiments were carried out in a batch process by using aqueous solution of Methlylene Blue. Variables parameters were initial Methlylene Blue concentration, adsorbent amount, contact time, temperature and $\mathrm{pH}$ of the medium. Standard solutions containing 50$1000 \mathrm{mg} \mathrm{l}^{-1}$ Methlylene Blue were prepared by dilution of dye stock solution containing 1000 $\mathrm{mgl}^{-1}$ of metal ion. All experiments were performed by using beakers of $100 \mathrm{ml}$ capacity containing 1-10 $\mathrm{g} \mathrm{I}^{-1}$ of biosolid suspended in $50 \mathrm{ml}$ of dye solution. The initial $\mathrm{pH}$ adjustment were carried out either by hydrochloric acid or sodium hydroxide solutions before adding the biosolid and was recorded as $\mathrm{pH}$ in. WTW (Inolab) $\mathrm{pH}$ meter was used for the $\mathrm{pH}$ measurements and was calibrated with buffer solutions at $\mathrm{pH} 4$ and $\mathrm{pH} 7$ prior to use.

The suspensions were mixed at predetermined periods (5-1440 $\mathrm{min}$ ) at constant temperature $\left(25^{\circ} \mathrm{C}\right)$ in a shaker at $150 \mathrm{rpm}$ until equilibrium was reached. The solution reaction mixture was centrifuged at $5000 \mathrm{rpm}$ for $20 \mathrm{~min}$ and the absorbance of dye solution was determined by The Pharmacia Nova Model spectrophotometer at a $663 \mathrm{~nm}$ wavelength, at which the maximum absorbency occurred. The amounts of dye adsorbed were calculated from the concentrations in solutions before and after adsorption.

\subsection{Biosolid preparation}

Waste sludge (biosolid) was taken from Cumhuriyet University Wastewater Treatment Plant consisting of mechanical treatment, activated sludge unit and belt filter press.

Domestic wastewater is given to treatment system. Biosolids were collected from belt filter press. The sludge was conditioned with lime before belt filtration. In the experiments, dry ground biosolids were used. The biosolid sample was ground and sieved to $0.0063-0.125 \mathrm{~mm}$ particle size and then washed with distilled water to remove any non-adhesive impurities and small particles, and then dried at $103^{\circ} \mathrm{C}$ for $24 \mathrm{~h}$ to remove moisture. The mineralogical features at samples were determined using Rigaku D Max III C X-ray diffractometer (XRD) in Cumhuriyet University. The results of XRD analysis demonstrated the main minerals to be portlandite and calcite (Figure 1).

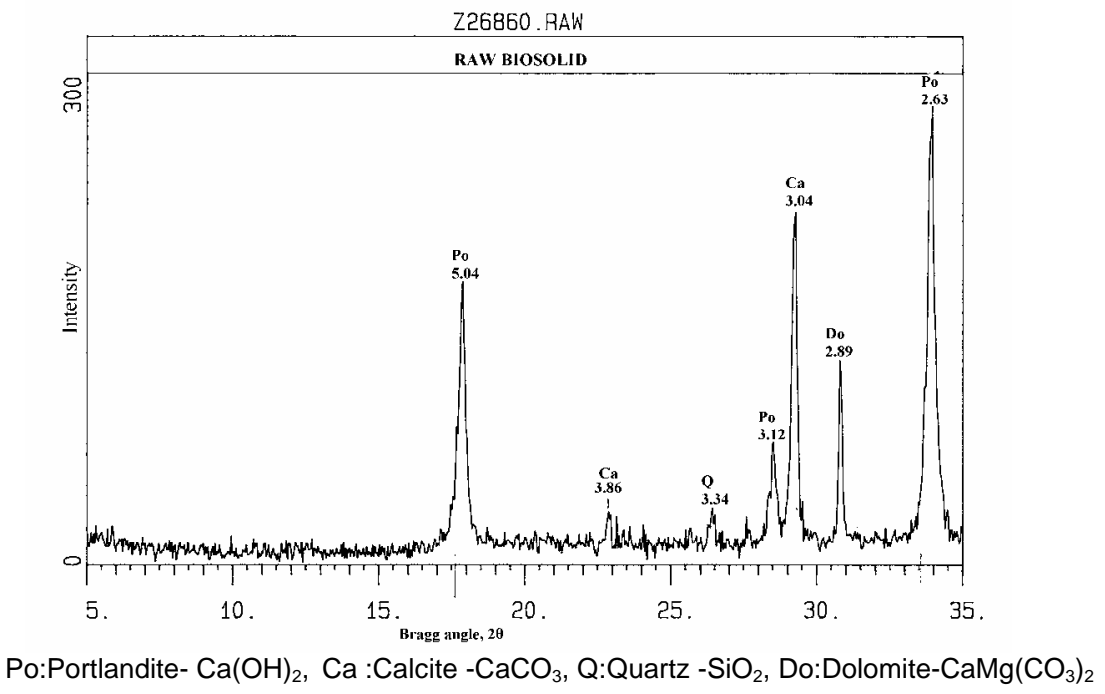

Figure 1. The results of X-ray diffraction analysis 


\subsection{Preparation of basic dye solution}

Methlylene Blue, $\mathrm{C}_{16} \mathrm{H}_{18} \mathrm{~N}_{3} \mathrm{SCl} .3 \mathrm{H}_{2} \mathrm{O}$, is a cationic dye. It was chosen in this study because of its known strong adsorption onto solids. The structure of this dye is shown in Figure 2. The dye is not regarded as acutely toxic, but it can have various harmful effects.<smiles>CN(C)c1ccc2c(c1)S[S+]=c1cc(N(C)C)ccc1=N2</smiles>

Figure 2. Structure of Methlyene Blue

Basic dye, Methlylene Blue, was used without further purification. Methlylene Blue was dried at $110^{\circ} \mathrm{C}$ for $2 \mathrm{~h}$ before use. All of the Methlylene Blue solution was prepared with distilled water.

The stock solution of $1000 \mathrm{mg} \mathrm{l}^{-1}$ was prepared by dissolving Methlylene Blue in $1000 \mathrm{ml}$ distilled water. The experimental solution was prepared by diluting the stock solution with distilled water when necessary.

\subsection{Batch adsorption experiments}

\subsubsection{Effects of initial dye concentration}

$1 \mathrm{~g}$ of biosolid as adsorbent with $100 \mathrm{ml}$ of dye solution was kept constant for batch experiments. Initial Methlylene Blue solution concentrations of $50,100,250,500,750,1000$ $\mathrm{mg} \mathrm{I}^{-1}$ were performed at $25{ }^{\circ} \mathrm{C}$ on a rotary shaker operated at $150 \mathrm{rpm}$ for $24 \mathrm{~h}$. Then optimum initial dye concentration was identified. The effects of adsorbent, contact time, adsorbent dosage, $\mathrm{pH}$ and temperature were conducted.

\subsubsection{Effect of contact time}

In these experiments, initial dye concentration was $250 \mathrm{mg} \mathrm{l}^{-1}$. The effect of contact time was investigated for $5,10,15,20,25,30,35,40,45,60,90,120,240$ and $1440 \mathrm{~min}$ at the pH 7 and $1 \mathrm{~g} / 100 \mathrm{ml}$ sample dosage.

\subsubsection{Effect of adsorbent dosage}

Initial Methlylene Blue solution concentration of $250 \mathrm{mg} \mathrm{I}^{-1}$ was used in conjunction with biosolid sample of $1,3,5,7,10 \mathrm{~g} \mathrm{l}^{-1}$. Contact times and $\mathrm{pH}$ were $120 \mathrm{~min}$ and 7 , respectively.

\subsubsection{Effect of $\mathrm{pH}$ and temperature}

Initial $\mathrm{pH}$ of solution was adjusted to $3,5,7,9$ and 11 at optimum condition of dye concentration, biosolid dosage, and contact time.

Effects of temperature on the adsorption process were studied at between $25-45^{\circ} \mathrm{C}$.

\section{RESULTS AND DISCUSSION}

\subsection{Adsorption rate}

Adsorption rate was investigated using the values of dye adsorbed at different initial dye concentrations, adsorbent dosage, $\mathrm{pH}$ and temperatures as a function of time.

\subsubsection{Effect of initial adsorbate concentration on adsorption process}

Initial concentrations of Methylene Blue solutions were changed in order to determine proper Methlyene Blue adsorption keeping the contact time $24 \mathrm{~h}, \mathrm{pH}$ of 7 . Figure 3 showed that the amount adsorbed qe ( $\mathrm{mg} \mathrm{g}^{-1}$ ) and percentage removal rate increased with an increase in the dye concentration. However, percentage dye removal rate $(99 \%)$ was constant after $250 \mathrm{mg} \mathrm{l}^{-1}$ of Methylene Blue concentration. Therefore, the following experiments were done by considering $250 \mathrm{mg} \mathrm{l}^{-1}$ of Methylene Blue concentration. 


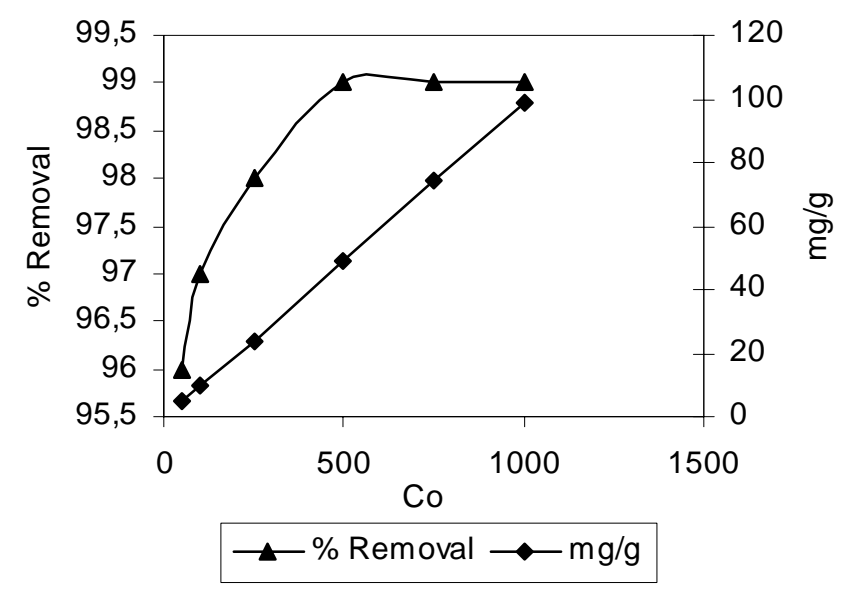

Figure 3. The effect of concentration on the result of Methylene Blue $\left(\mathrm{pH} 7, \mathrm{~T} 25^{\circ} \mathrm{C}\right.$, adsorbent dosage $1 \mathrm{~g} \mathrm{I}^{-1}$, contact time $24 \mathrm{~h}$ )

\subsubsection{Effect of contact time on adsorption process}

The effect of contact time on the amount of dye adsorbed was investigated at the optimum initial concentration of dye. The extent of removal (in terms of qe) of Methylene Blue by biosolid was found to increase, reach a maximum value with increase in contact time (Figure $4 a$ and $4 b)$. In same cases it almost become constant with increase in contact time, after 120 min. based on these results, 120 min was taken as the equilibrium time in adsorption experiments. The removal of Methylene Blue from aqueous solutions by adsorption on biosolid increases with time, till the equilibrium is attained. Similar results have been reported in literature for removal of dyes [2, 15].

In batch type adsorption process monolayer of adsorbate is generally formed on the surface of adsorbent [16] and removal rate of adsorbate species from aqueous solution is controlled especially by the rate of transport of the adsorbate species form the outer sites to interior sites of the adsorbent particulars [2].

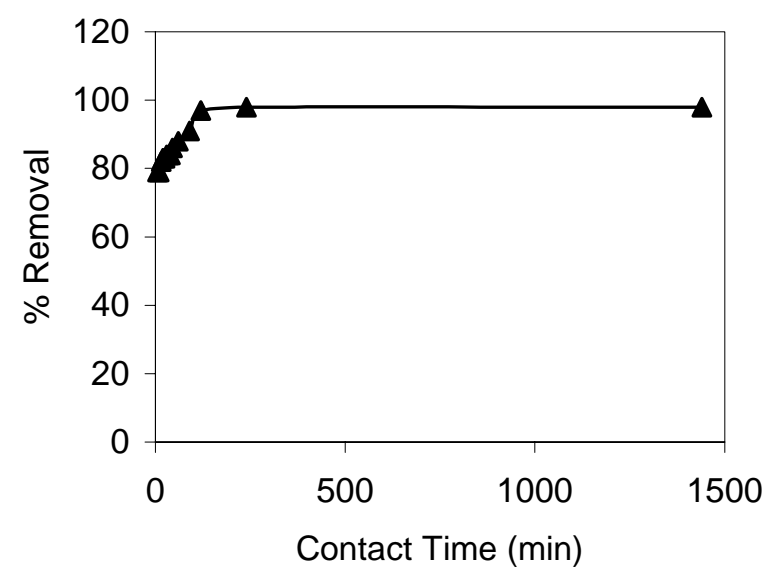

Figure $4 \mathrm{a}$. The effect of contact time on the results of Methlylene Blue $\left(\mathrm{pH} 7, \mathrm{~T} 25^{\circ} \mathrm{C}\right.$, Adsorbent dosage $1 \mathrm{~g} \mathrm{l}^{-1}$, initial concentration $250 \mathrm{mg} \mathrm{l}^{-1}$ ) 


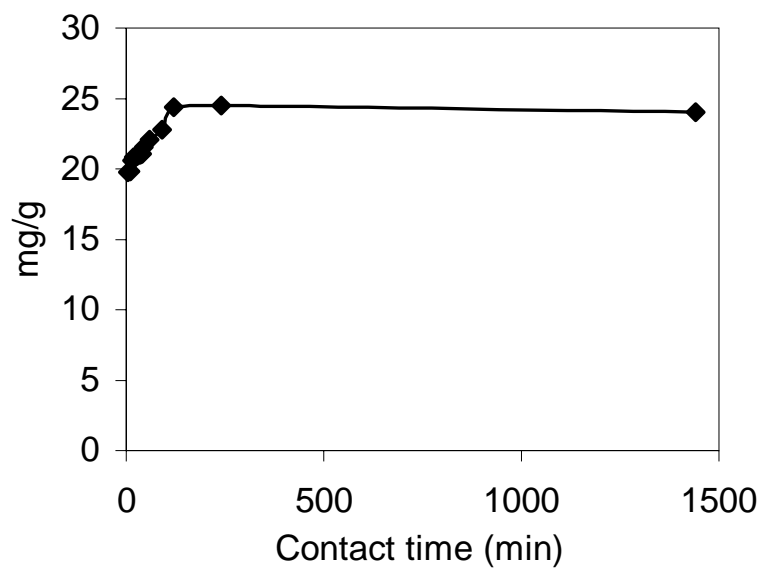

Figure $4 b$. The effect of contact time on the results of Methlylene Blue $\left(\mathrm{pH} 7, \mathrm{~T} 25^{\circ} \mathrm{C}\right.$, Adsorbent dosage $1 \mathrm{~g} \mathrm{I}^{-1}$, initial concentration $250 \mathrm{mg} \mathrm{l}^{-1}$ )

\subsubsection{Effect of adsorbent dosage on adsorption process}

The adsorption of dyes increased with the sorbent dosage and reached an equilibrium value after $0.7 \mathrm{~g}$ of sorbent dosage (Figure 5). As one was expected, the percentage of dye removal increased with increasing amount of biosolid, however the ratio of dye sorbed to biosolid ( $\mathrm{mg}$ $\mathrm{g}^{-1}$ ) decreased with the increasing amount of biosolid.

The ratio of dye sorbent to biosolid was started to reach equilibrium at $0.7 \mathrm{~g}$ biosolid. When the biosolid was increased from 0.7 to $1 \mathrm{~g}$, the ratio of dye sorbed to biomass $\left(\mathrm{mg} \mathrm{g}^{-1}\right.$ ) showed no significant change. Thus $1 \mathrm{~g}$ of biosolid was chosen for next study on the effect of $\mathrm{pH}$ and temperature.

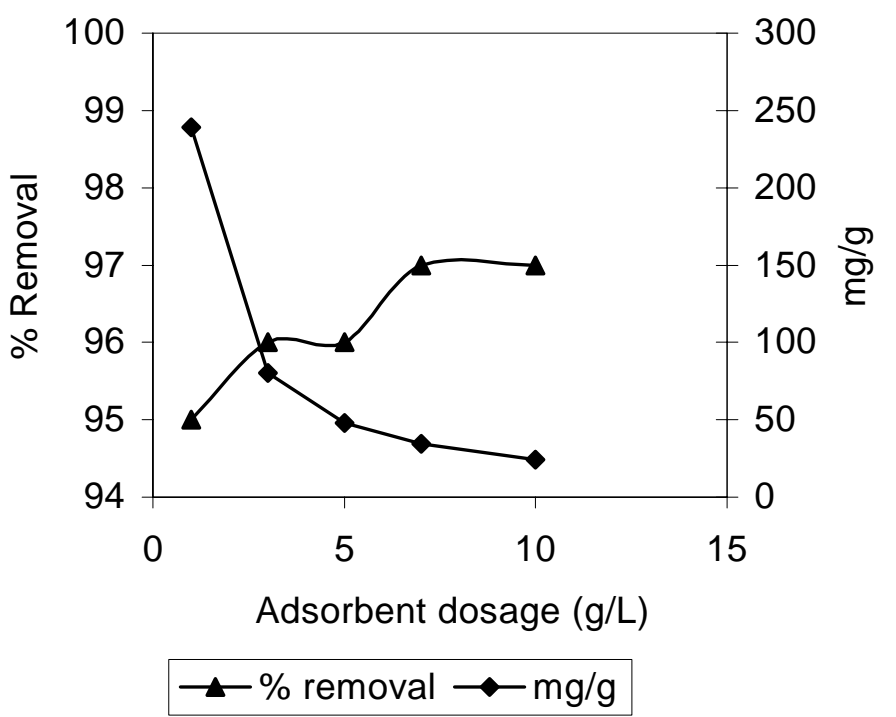

Figure 5. The effect of adsorbent dosage on the results of Methlylene Blue $\left(\mathrm{pH} 7, \quad \mathrm{~T} 25^{\circ} \mathrm{C}\right.$, initial concentrating $250 \mathrm{mg} \mathrm{l}^{-1}$, contact time $120 \mathrm{~min}$ )

\subsubsection{Effect of temperature on adsorption process}

Temperature has important effects on the adsorption process. As the temperature increase, rate of diffusion of adsorbate molecules across the external boundary layer and interval pores of the adsorbent particle increase [12]. Changing to temperature will change the equilibrium capacity of the adsorbent for particular adsorbate $[12,17]$.

Figure 6 shows effects of different temperatures for Methylene Blue adsorption on biosolid. The removal of Methylene Blue by adsorption on biosolid increases slightly from 24.4 to 24.88 
$\mathrm{mg} \mathrm{g}^{-1}$ by increasing temperature of the solution from 25 to $45^{\circ} \mathrm{C}$, indicating the process to be endothermic.

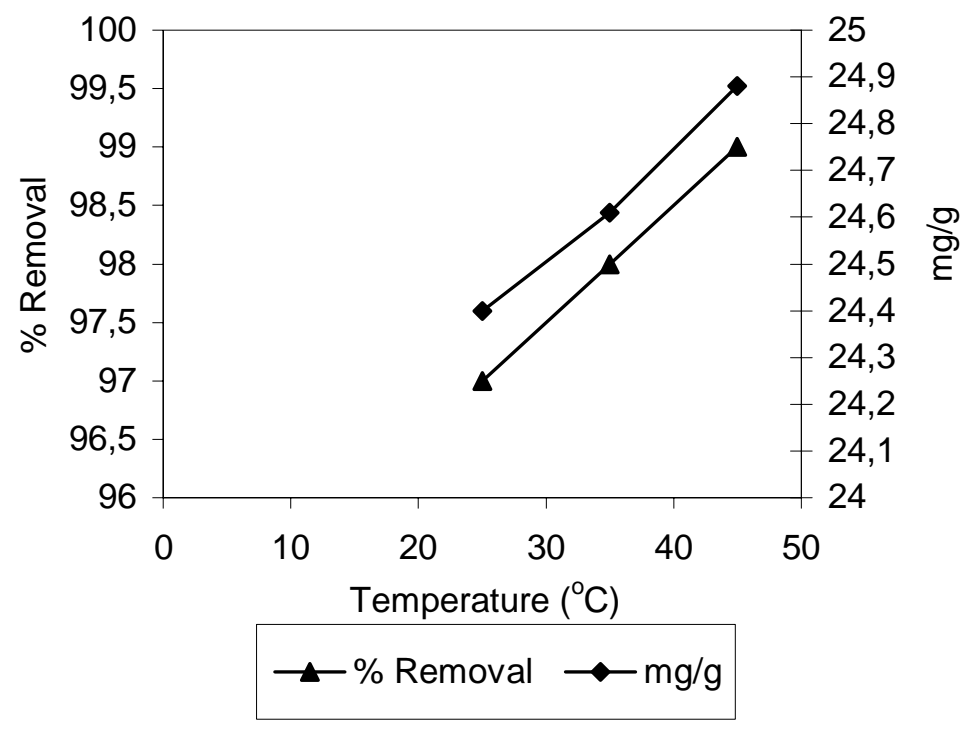

Figure 6. The effect of temperature on the results of Methlylene Blue $(\mathrm{pH} 7$, initial concentrating $250 \mathrm{mg} \mathrm{l}^{-1}$, contact time $120 \mathrm{~min}$, adsorbent dosage $10 \mathrm{~g} \mathrm{l}^{-1}$ )

\subsubsection{The effects of $\mathrm{pH}$}

The $\mathrm{pH}$ is one the most important factors controlling the adsorption of dye on to adsorbent. As the $\mathrm{pH}$ increases, it is usually expected that adsorption also increases. Fig 7 shows the adsorptions of dye at different pHs (3-11) as a function of reaction time. In this study $\mathrm{pH}$ did not importantly effect the dye removal. However, the maximum adsorption capacity was found as 24.40 at pH 7. Above and under this point, adsorption of Methylene Blue on biosolid tends slightly to decrease. So pH 7 was chosen for the study on adsorption isotherm.

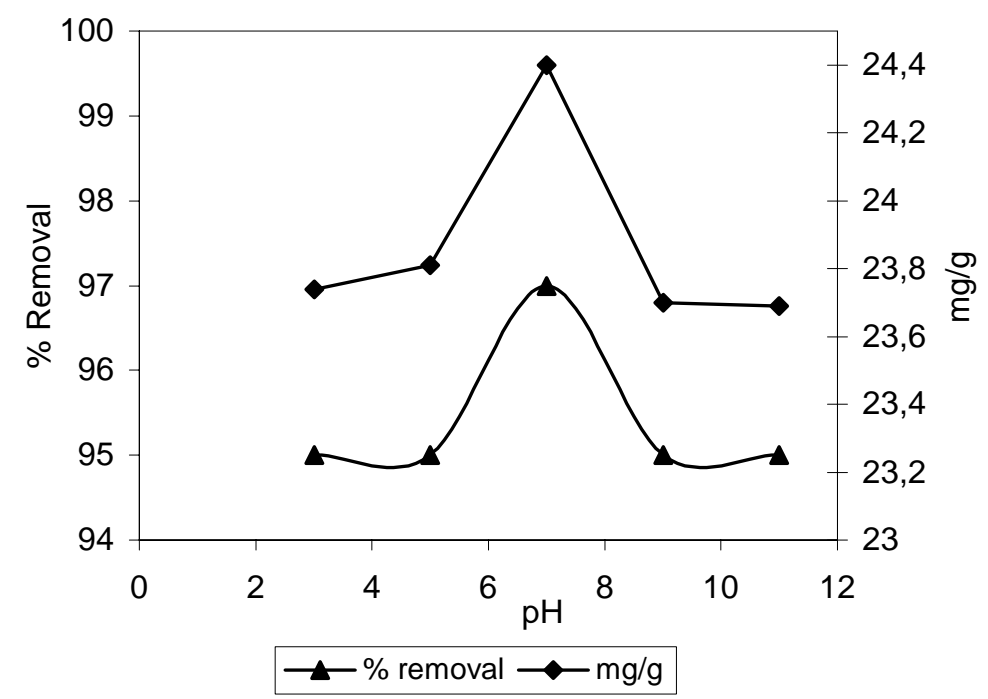

Figure 7. The effect of $\mathrm{pH}$ on the results of Methlylene Blue (Initial concentrating $250 \mathrm{mg} \mathrm{I}^{-1}$, contact time $120 \mathrm{~min}$, adsorbent dosage $10 \mathrm{~g} \mathrm{I}^{-1}$, temperature $25^{\circ} \mathrm{C}$ )

\subsection{Adsorption isotherm}

The adsorption data were analysed with the help of linear form of Freundlich isotherm. Freundlich model attempts to account for surface heterogeneity [18].

Freundlich isotherm:

$$
\text { Log } q e=\log k_{f}+(1 / n) \log C e
$$


where $\log k_{f}$ is roughly a measure of the adsorption capacity and $1 / n$ is an indicator of adsorption effectiveness; qe is the amount of dye adsorbed per unit mass of adsorbent (in $\mathrm{mg}$ $\mathrm{g}^{-1}$ ) and $\mathrm{Ce}$ is the equilibrium concentration of dye (in $\mathrm{mg} \mathrm{l}^{-1}$ ). The values of Freundlich parameters were obtained from the linear correlations between values of log qe versus log $\mathrm{Ce}$. The Freundlich isotherm parameters along with the $\mathrm{k}_{\mathrm{f}}$ and $\mathrm{n}$ were found as 1.21 and 0.39 , respectively $\left(R^{2}=0.999\right)$. The Freundlich coefficient, $n$, which should have values in the range of $0<\mathrm{n}<1$ for favorable adsorption $[5,18]$.

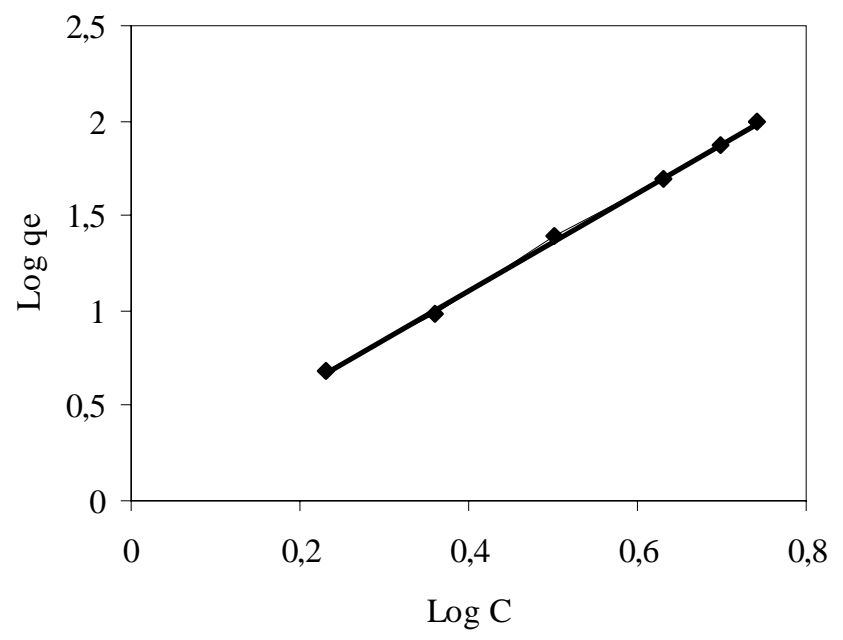

Figure 8. Freundlich isotherm

\section{CONCLUSION}

Biosolid is a promising adsorbent for removal of the cationic dye, Methylene Blue from water. $1 \mathrm{~g} \mathrm{l}^{-1}$ of adsorbent could almost completely decolorize solution of Methylene Blue (250 mg $\left.{ }^{-1}\right)$. The equilibrium adsorption is achieved in $120 \mathrm{~min}$. The solution of $\mathrm{pH}$ and temperature did not have important effect on the extent of adsorption of the dye on biosolid, it could be considered that the $\mathrm{pH}$ of the medium controlled the adsorption process. The experimental data fit with Freundlich isotherm. The surface of the biosolid particles was heterogeneous, non-specific and non-uniform in nature.

The adsorption of Methylene Blue on biosolid was slightly endothermic. This indicates that a temperature above the $25^{\circ} \mathrm{C}$ would be favorable for removal of the dye. However, adsorption is quite high even at ambient temperature.

\section{REFERENCES}

1. Bhatnagar A. and Jain A.K. (2004) A comparative adsorption study with different industrial wastes as adsorbents for removal of cationic dyes from water, Journal of Colloid and Interface Science, in press.

2. Kannan N. and Sundaram M.M. (2001) Kinetics and mechanism of removal of methylene blue by adsorption on various carbons- a comparative study, Dyes and Pigments , 51, 25-40.

1. 3 Isık M. and Sponza D.T (2005) A batch study for assessing the inhibition effect of Direct Yellow 12 in a mixed methonogenic culture, Process Biochemistry, 40, 1053-1062.

3. Kargi F. and Ozmihci S. (2004) Biosorption performance of powdered activated sludge for removal of different dyestuffs, Enzyme and Microbial Technology, 35, 267-271.

4. Bhattacharyya K.G and Sharma A. (2005) Kinetics and thermodynamics of Methylene blue adsorption on Neem (Azadirachta Indica) leaf powder, Dyes and Pigments , 65, 51-59.

5. Walker G.M. and Weatherley L.R. (1998) Fixed bed adsorption of acid dyes onto activated carbon, Environmental Pollution, 99, 133-136.

6. Chern Jia-Ming and Wu Chia-Yuan. (2001) Desorption of dye from activated carbon beds: effects of temperature, $\mathrm{pH}$ and alchol, Water Research, 35, 4159-4165.

7. Namasivayam C., Muniasamy N., Gayatri K., Rani M.and Ranganathan K. (1996) Removal of dyes from aqueous solution by cellulosic waste orange peel, Bioresource Technology , 57, $37-43$. 
8. Namasivayam C, Prabha D, Kumutha M. (1998) Removal of direct red and acid brillant blue by adsorption onto banana pith, Bioresource Technology, 64, 77-79.

9. McKay G., Ramprasad G. and Mowli PP.(1986) Equilibrium studies for the adsorption of dyestuffs from aqueous solution by low-cost materials, Water, Air and Soil Pollution, 29(3), 273-283.

10. Ramakrishna K.R. and Viraraghavan T. (1997) Dye removal using low cost adsorbents, Water Science Technology, 36, 189-196.

11. Dogan M., Alkan M., Turkyilmaz A. and Ozdemir Y. (2004) 'Kinetics and mechanisms of removal of methylene blue by adsorption onto perlite', Journal of Hazardous Materials $B, 109$, 141-148.

12. Waranusantigul P., Pokethitiyook P., Kruatrachue M. and Upatham ES. (2003) Kinetics of basic dye (methylene blue) biosorption by giant duckweed (spirodela polyrrhiza)', Environmental Pollution, 125, 385-392.

13. Otero M., Rozada F., Calvo L.F., Garcia A.I. and Moran A. (2003) Kinetic and equilibrium modeling of Methylene Blue removal from solution by adsorbent materials produced from sewage sludges, Biochemical Engineering Journal, 15, 59-68.

14. Mc-Kay G., Otterburn M.S. and Aga J.A. (1985) Fulters earth and fired clay as adsorbents for dyestuffs-equilibrium and rate studies, Water Air Soil Pollution, 24(3), 307-322.

15. Weber Jr. WJ. (1972) Physico-chemical processes for water quality control, New York; Wiley Inter Science.

16. Al-Qodah Z. (2000) Adsorption of dyes using shale oil ash, Water Research, 34(17), 42954303.

17. Shahwan T. and Erten H.N. (2002) Thermodynamic parameters of $\mathrm{Cs}^{+}$sorption on natural clays, Journal of Radioananalytical and Nuclear Chemistry, 253 (1), 115-120. 